\title{
6. Looking backwards to the future: The evolving tradition of ideal political rhetoric in Australia
}

\author{
Mark Rolfe
}

In 2007 Robert Manne extolled the television series The West Wing as a model for what leaders and political rhetoric should be in contrast to 'what ... democratic politics is not' under John Howard, 'one of the most unscrupulous but effective politicians in our history'. The program is 'so attractive (and perhaps ultimately fictitious)' because 'despite their willingness to play the game according to its inescapable rules, no corrosion of character has taken place in any of the players'. There was real grand debate between Senator Arnie Vinick, played by Alan Alda, and Congressman Matt Santos, played by Jimmy Smits. 'Both candidates are granted rhetorical victories', wrote Manne, 'The debate has been spirited, occasionally angry, but sharp and clean. The candidates' handshake at its conclusion is a moment of genuine political epiphany'. For Manne, everyone was elevated rather than degraded by the experience (2007: 12-13).

Manne is not alone with such fervent political desire for the elevation of the quality of politics and of political language. There has been a habitual tendency in Australia to think that the current state of political discourse is appalling and to envisage what it should be like, drawing frequently on an imagined past when political leaders and their rhetoric were better. 'Soaring political oratory' existed 'back then' for the journalist Annabel Crabb. She doesn't tell us when, but we know it was eventually killed by the sound bite, the 24-hour news cycle and social media (Crabb 2013). A similarly mysterious 'back then' lurks in a book by Lindsay Tanner, an ex-Labor politician who vented his spleen at social media, trivia and celebrity promoting the constant media cycle and degrading politics (Tanner 2012).

The problem with such analyses is that nostalgia does not withstand closer historical investigation. Ultimately, we arrive at the quip that 'nostalgia ain't what it used to be'. But that still leaves the question of why people resort to these historical longings. To wit, I argue that creative imaginings of past leaders and their rhetorics have been essential standards for judging current leaders and their language principally because there is no abstract universal point for judging this discourse.

This argument has a necessarily historical dimension that needs exploration. Depictions of 'back then' or the 'good old days', when leaders and their language 
were better, have been part of representative democracies since the early nineteenth century, even 'back then' in those supposed better days. This is not only the case in Australia, but also in those countries to which Australians looked - Britain and America. They have a common myth about the political past and for generations they have shared discussions about great leaders of the past, although it must be said that America led the way as the first representative democracy.

Such idealisations of political leadership and political rhetoric have been intrinsic to an evolving tradition of myth-making about admired political leaders, which is then used in partisan politics to judge the current crop of politicians and candidates. General themes of great leadership are deployed in contextualised circumstances. Competitors for office must try to measure up to these exacting standards, while simultaneously warding off the disrepute associated with the stereotype of the despised politician and pushing it in the direction of opponents. The rhetoric of anti-politics is a powerful accompaniment.

This tradition necessarily involves complex manoeuvres of ethos by politicians with popular audiences. Politicians battle each other in partisan games around ethos, willing to foster the stereotypical disrepute in others while not exciting suspicions of their own ethos. In part these games are played with idealised notions of rhetoric and of great leaders, which are counter posed to exaggerated notions of unruly or deceitful language and stereotyped politicians. This myth-making happens in tandem with a popular revulsion for stereotypical politicians and their disreputable vocation and with popular demands for political candidates who live up to the mythical ethos.

\section{Myth, tradition and rhetoric}

My argument does not depend on a notion of myth as falsity. Rather, political myth-making is 'a normal feature of political life ... linked to the existence of competing sets of ideological beliefs about what society is and how it ought to be' (Flood 2002: 11-12). It is a species of rhetoric engaged in the deliberative genre that appeals to the collective memory of historical events; for example, the foundation of Rome, the Magna Carta, the French Revolution, the American Revolution or, in the case of this chapter, American presidents. Such memories are not nuanced accounts, but neither are they fabrications. They do have a semblance of fact and truth to them, but at the same time, they are guilty of simplification and anachronism. To be fair, though, such sins can also be committed by scholars who impose their priorities on the past and make familiar much that is alien. For example, political theorists have a provisional and ambivalent relationship with history 'as a quarry' for their enterprise (Condren 
1997: 45). Clearly, the need for scholarly sensitivity to historical context points us to the more common human dilemma of hermeneutic interpretation that troubles the public and academics alike.

For both Flood (2002) and Tudor (1972: 132), myth is a narrative that serves ideological functions, specifically in competitions over 'what society is and how it should be'. Consequently, it connects the treasured beliefs and figures of a social group in a sequence of events in what purports to be a true account. It must therefore be 'sufficiently faithful to the interpretation of facts, sufficiently faithful to the relationship between facts, and sufficiently faithful to their meaning and significance' to ensure that it cannot be discredited as mere fantasy, irrationality or distortion (Flood 2002: 9).

Political myth has validity to a social group, says Flood, which is why it is a rhetorical resource for different groups to deploy in contests. Any rhetor of that social group must take myths seriously if they want to be taken seriously. In that respect, we can see a link between political myth and what is called in rhetoric endoxa. That is, a rhetor must resort to the common knowledge and beliefs of a group as the basis of unexpressed presumptions and conclusions in arguments (Tardini 2005) that have a tentative plausibility for an audience (Walton 2007: 12-13). Endoxa form the basis of informal reasoning in persuasion and explain why political myths are reproduced through a social group: as widely shared endoxa, they are powerful resources for arguments. Of course, this also means they are used in political contests within that community.

Given the reasonable grounds for a social group to indulge in a political myth over time, this reproduction connects directly to the concept of rhetorical tradition. In his exploration of American democratic discourse Russell Hanson defined rhetorical tradition as 'an historically extended, socially embodied argument' over the meanings of essential and widely admired ideas (1985: 23-24). Over generations, Americans have debated the meaning of democracy because it is a prized and widely shared belief, otherwise people would not fight for it. Despite being a valued belief, however, this does not mean that democracy is a simple concept. On the contrary, democracy is widely accepted as a complicated entity (Saward 2003; Sartori 1987). It is no wonder there is no single model of democracy that has stamped political societies across the world, but a plethora of adaptations that arise according to circumstances and of tinkering resulting from persistent debate.

In fact, says Hanson, the historically extended argument exists because democracy is a contested concept open to continual debate and dispute (1985: 23-24). Numerous scholars agree that there are three areas that complicate any arrival at consensus in argument over the term. That is, contest arises over the definition of democracy, over the application of the definition to events, 
and over the social attitudes it displays (Connolly 1983). Argument between debaters may occur over the criteria that make up the definition of democracy. Even if by some minor miracle agreement can be gained between them over definition, disagreement may still ensue over the application of that definition. Furthermore, debaters will use the term with a social attitude or evaluation that provokes dissension. The nature of democracy lends itself to continuous conflict and, so, it is always being constituted and reconstituted through persistent argument as each generation of citizens seeks to make democracy meaningful to themselves.

By implication, one may add that such continual rhetorical construction is not unique to America, but is inherent to all meaningful representative democracies, including Australia. Moreover, these societies are continually feeding each other with insights, arguments and discontents because of their common interest in debating the meaning of democracy. This is most obvious in the fact that Manne drew on an American television show to make a local point. But he is not the first Australian to do this. One can trace our habit of looking to America to the 1820s. After all, America was the first representative democracy, for its white males if not for others, and it created examples for others to contemplate, discuss, borrow and adapt. It is therefore necessary to turn to America to see how their imaginings of leadership and language began and functioned.

\section{The West Wing and ethos}

Clearly, Manne loved The West Wing, and one can assume that, like so many devotees, he idolised President Josiah 'Jed' Bartlet. Although the writers of the show were liberals with a contempt for George W. Bush always in the back of their minds, Bartlet's impeccable ancestry and convictions displayed their devotion to core American principles beyond partisanship. For a start, they cast him as a descendant of one of the signers of the Declaration of Independence.

This lineage is connected to ideals of public service to others: to ideals rather than to selfish materialist pursuits. We know that Bartlet followed the contemplative life through the priesthood and academia, yet he also pursued the active life of politics where he applied his knowledge of economics for the benefit of the people. He was still the sometimes-formidable professor with a predilection for historical, literary and biblical allusions, thus further hinting at the Platonic ideal of the philosopher-king, which hovers in the background. He was faithful to his wife, family and religion, which is very much in line with the popular expectations of an American political candidate. Tragically, but also typically in line with the stories of presidential martyrdom, he suffered multiple sclerosis for 
his people - which echoes Franklin D. Roosevelt's polio - a disease that will be given no quarter until he has laid down the mantle of office in accordance with his oath to others.

Thus, in his fictional biography, Bartlet satisfied the threefold categories that make up ethos, the rhetorical term for credibility with an audience. No matter how much we think rhetoric should be based on logic, audiences will not listen if they don't respect the orator. In fact, according to Aristotle, the prime proof (pisteis) for all audiences is the credibility and reputation of the speaker. They need to be persuaded of the practical wisdom (phronesis), benevolence to others (eunoia), and excellent moral character (arête) of the orator (Rolfe 2008). Bartlet proves himself in all three areas, which is why we find him so easily admirable and why we expect to find these attributes in all political candidates who wish to woo voters.

For many people, a focus in politics on the person is wrong; a shallow concern with image rather than a serious focus on issues, on personalities when it should be on policies. Such nostrums are regularly repeated at every election, says Trevor Parry-Giles citing another scholar, yet it is a 'treacherous piety' since:

Human beings make up a government, not 'measures' or 'issues'. The quality of a government is thus a function of the quality of Leadership, not of the policies advocated by that government. (2010: 39)

Whether a person is suitable for the top political job in the land is not a trivial matter. We can justifiably expect that a president or prime minister should display self-mastery and good judgement (unlike, for example Labor leader Mark Latham when seeking office in 2004) and have the right sort of education and experience to make sensible decisions. Finally, we should rightly expect that a leader has the prudence (phronesis) to calculate ends and means with regard to both particular situations and general principles so as to leave the community better off. This requires levels of implementation, effectiveness and achievement that acquire legitimacy with a community. It was over such specifics, for example, that both Kevin Rudd and Julia Gillard had problems, with consequent damage to their ethos and difficulties with voters listening to them during their terms as prime minister. For these reasons of ethos, it is understandable that fantasy and mythical presidents have a place in political debates about the quality of leadership. However abbreviated they may seem from a scholarly point of view, as endoxa they provide some standards to discuss current political leaders and hopefuls. 


\section{Imagined presidents and the American jeremiad}

Paradoxically, it is the fantasising about Bartlet's ethos that has deep American antecedents and proves it is not unwarranted. Drawing on Benedict Anderson's notion of imagined communities, Jeff Smith observed in his assessment of American presidents that 'If nations themselves are imaginative constructions, their leadership is even more so. Rulership of any kind is an essentially metaphorical act, a community's projection of authority onto an individual in much the same way that love is metaphorically projected through a red rose' (2009: 7). And, we may add, if political leadership is imagined then so is political rhetoric.

The intellectual material for imagining American presidents existed long before George Washington became president; after all 'the presidency had to be imagined before it could be created' (Smith 2009: 7). Much of this can be traced to England during the time of Robert Walpole's premiership and developments of parties, partisanship and the early Westminster model (Smith 2009; Bailyn 1968). His Robinocracy, as it was called, was accused of gross corruption of public monies and deplorable lies. But for the most part, these sallies came from his Tory opposition. As well, they counter posed such negatives to idealisations of a unifying patriot king beyond politics. It is an early lesson in the same rhetorical ploy advanced by Manne some 300 years later. Portrayals of ideal leadership have a partisan context, but at the same time have an anti-political thrust to them. This unusual rhetorical combination easily travelled the Atlantic to the American colonies where it became standard fodder for politics.

None of this background detracts from the fact that Washington was widely admired during his lifetime, so much so that he eased the anxieties of many attendees at the convention of 1787 about the new presidency that they were creating. Nevertheless, his personality could not resolve the vagaries of the new office and its tensions with the legislatures within a system of checks and balances designed to force separation and cooperation. Power was not only shared between president and congress but also with states and an overseeing Supreme Court. Yet distrust of political power, fed by intellectual inheritance and revolutionary experience, was tempered for the attendees by realisation of the weakness of the executive they created in the first confederation of 1781 . As a result they bolstered the position of president. Still, their novel political creation was a recipe for continuing dispute over the role and extent of this single national political institution in the land. This immediately manifested in battles between Federalists and Anti-Federalists, as they were called, the centralisers and anti-centralisers of political power.

Of course, the vagaries and complexities were only temporarily alleviated by Washington's reputation while he was alive. He became a modern day Cincinnatus; 
even his army officers called themselves 'Society of the Cincinnati', a reference to the humble Roman aristocrat and consul who became a legend of selfless civic virtue for saving the republic in its time of need and for returning to the farm plough rather than holding to power. He appealed to Americans wary of those who liked power too much. Given all this, Washington's death ensured that a larger than life mystique soon enveloped the man as a standard for leadership. He became the epitome of perfect political leadership for a perfect republic. By the new century each side was fighting for the mantle of the great man.

This tendency merged with another American twist to European ideas. John Dunn has written that 'that democracy entered the ideological history of the modern world reluctantly and facing backwards' with one eye on Athenian democracy (2006: 39). But one may also say that Americans were also looking backwards to the beginning of their republic. From around 1800 political partisans bewailed opponents for corruption of the 'New Jerusalem' so distinct from corrupt aristocratic Europe. Here was the rhetoric of the American jeremiad, a narrative that harks back to the mixed religious and political ideals of America as a 'shining city on the hill' girded by a covenant with God. In line with the distant Puritan forebears, the American Founding Fathers were deemed to be renewing the covenant of their country as both a religious and secular perfection (Bercovitch 1978: Chpt 1).

Thus, the combined legacies of American jeremiad and Washington mystique decreed a tremendous narrative for future citizens to cherish, but a tremendous challenge for future politicians to meet. There were bound to be disappointments, especially when with time, retrospection and partisan competition politicians were judged against an evolving 'invented tradition' of a few mythologised presidents (Kazin 1998: 21). Washington obviously set the tradition, but he was gradually joined by Thomas Jefferson and Andrew Jackson and then, many decades later, by Abraham Lincoln and Franklin D. Roosevelt. All were subject to partisan abuse during their lifetimes, but were eventually elevated after death to a non-partisan pantheon of great leaders of the republic. They became yardsticks to measure others and mourn a perceived loss to politics; the political mythology of the nation was continued through personification. It was an easy recipe for any capable political orator to cultivate disappointment in an opponent and promote a favourite alternative. It also meant that political nostalgia for past leaders was embedded from the beginning.

\section{Public opinion and rhetoric}

Such rhetoric became political fodder after major political developments. The extension of the white male franchise in the 1820s changed politics from an 
exclusive gentlemen's game to an inclusive participatory culture. Public opinion was now a force to be reckoned with and the following decades amplified this force with the evolution of the 'penny press', transport and communication (Schudson 1978). For the rest of the century, says Andrew Robertson, there was thematic recurrence in American discourse because of the profound need to persuade the masses (2005: vii). From such origins populism became an essential part of political life in the United States and a 'persistent yet mutable style of political rhetoric' that continues to the present (Kazin 1998: Chpt 1). The American jeremiad had a new lease of life in party politics for the masses, a rhetoric constantly positing the betrayal of the special mission of that nation and the Founding Fathers and demanding a return to the original values through the ejection of certain politicians and the election of others. Disappointment with the present was ever present.

Rhetoric became more hortatory in order to rouse the emotions and values of the populace and more admonitory in order to rouse partisanship and warn of the failures resulting from wrong political choice at election time. In addition, this popular style required familiarity with the people and demanded bluntness that valued truth over politeness. The old gentlemanly decorum of dignified reserve and distance by which one had shown respect for others was now replaced by a new decorum that demanded one be friendly and familiar in order to show respect (Cmiel 1990: Chpt 2). The requirements of ethos changed accordingly.

This was the beginning in public political debate of 'plain speaking' and of personal invective by those considered outside gentlemanly circles. Jackson built his anti-authoritarian political ethos assaulting 'aristocrats' and using the new 'stump speaking' (Eastman 2009: 184). This was indicative of a larger change in ethos as a 'man of the people'. For example, in the chase for popular attention, in 1824 Jackson began a tradition of presidential campaign biographies that have followed the same narrative contours to the present, emphasising the rise of an ordinary man of the same ilk as the voters. Repeatedly, the men were depicted as devotees of Cincinnatus, just like Washington (Brown 1960: 83-89). Many politicians acquired a familiar or folk decorum in order to fulfil the ethical expectations of their audiences. The word slang, which was once a synonym for vulgar in the previous century, was now associated with an informal style of language that signalled class associations.

The middling style of rhetoric had arrived in America, much to the consternation of gentlemen who thought it cheapened politics and broke traditional cultural boundaries. It appalled the likes of Henry Clay, the representative of Kentucky in both chambers of congress and thrice presidential candidate, who was revered as a link to the revolutionary era. To such refined critics, middling style 
mixed high and low, the erudite and the folksy, such that lapses in style were considered lapses in character. But we can also see how such views lined up with the politics of democracy. Clay was a bitter enemy of Jackson.

\section{Australia and battles over rhetoric}

As America underwent these political struggles as the sole and, later, leading example of white male representative democracy, so these developments were communicated to Australia and the world in what may be called the intricacies of Americanisation. This process did not entail the story of an aggressive Other imposing its culture upon a vulnerable Australia. The transmission was rather more complicated, selective and adaptive and worked at several levels; much passed unnoticed while controversy settled on some of the more noticeable or superficial elements (Rolfe 1997). Adding to the complexity was the tendency to cast America as both a promise and a threat:

From early days the United States has had a curious and very entertaining career in Australia as a kind of storehouse of ideas to be raided, a powerfully justifying precedent to be invoked or a dreadful example with which to shame the thoughtless. (C. Hartley Grattan cited in Rolfe 1997)

Although comparisons of an imagined Australia with an imagined America were made before 1788, it became common to think in the Antipodes and the British Colonial Office that the two countries were treading similar paths. For decades until colonial self-government in the 1850s, such comparisons emerged as ominous warnings or progressive hopes that disputes between Britain and her colonies would lead to war, independence and republicanism following the American precedent.

Writers often saw Australia as 'a new America', another America, 'the Future America', a 'humble imitation of the United States', 'the United States of Australia', the 'America of the South'. Or, as English Liberal politician Sir Charles Dilke remarked in 1867, 'In Australia, it is often said, we have a second America in its infancy' (McLachlan 1977: 367). Australia was often cast as a younger sibling, treading somewhere behind its elder 'Brother Jonathan'. As a result and from earliest days, Australians were abreast of even minor developments in America. For example, Australians could read the political wisdom in Benjamin Franklin's autobiography while expounding upon 'John Bull' (Britain), Brother Jonathan and some local political matter (Anonymous 1829a: 3). So it is not surprising that the work of Alexis de Tocqueville elicited early interest here and influenced the British Colonial Office when granting measures of government in 1842 and 1850 (Patapan 2003: 6). 
The identity of Australia in the nineteenth century was explicitly relational, with America and Britain serving as contrasting points of reference. Few sought actual revolution and republic; most only aimed at prising political reform from the Colonial Office or local authorities while staying firmly within the imperial fold. Warnings and wishes were issued in the context of local politics, such as the development of representative institutions, disputes over land distribution, and protests against restoring transportation of convicts in the late 1840s.

The explorer, barrister, landowner and politician William Charles Wentworth was typical of many people in his time with his regard for both Britain and America. In 1819 he imagined Australia's own War of Independence being fought in the Blue Mountains. In 1824 he and Robert Wardell started the Australian newspaper and agitated for a free press, trial by jury and a local house of assembly. Decades later Wentworth approvingly cited de Tocqueville when debating the 1853 New South Wales Constitution Bill. He also attracted derision for his idea of a local aristocracy for the upper house and for being a conservative old fogy.

But the idea was evident in 1825 when he and Wardell reproduced sections of a letter in which the author discussed development 'of the highest importance, viz. the formation of a wealthy and high-minded Aristocracy'. This was happening in America and would happen in Australia where things were 'not yet ripe for Representative Government' (Anonymous 1825: 2). Here was debate about representative institutions, quality of leadership and British constitutionalism, which for many embodied the Aristotelian mixed constitution of monarchy, aristocracy and democracy.

Typically, Wentworth and Wardell reproduced in 1831 a section from Thomas Paine's Rights of man discussing the 'grafting [of] Representation upon Democracy' in America. They included the magnificent praise: 'What Athens was in miniature, America will be in magnitude. The one was the wonder of the ancient world; the other is becoming the admiration, the model of the present.' Representative government, they continued, 'exists not by fraud and mystery, it deals not in cant and sophistry; but inspires a language that, passing from heart to heart, is felt and understood' (Anonymous 1831: 4).

Here was an idealisation of democratic discourse that resembles the imaginings elsewhere in this chapter and purports a true congruence with the people over other forms of political society that spread insincerity. The section includes Paine's discussion of the qualities of an American president, where 'more power is delegated ... than to any other individual member of Congress', and declares 'that no man in his sober senses will compare the character of any of the kings of Europe, with that of General George Washington'. 
Such discussions are a much earlier demonstration of the point made by Gregory Melleuish that politics after the granting of responsible government to New South Wales in 1856 was not so much understood 'in terms of institutional design but focused rather on quality of leaders'. Certainly, citizens looked to British civilisation, British constitutionalism and British traditions because they believed themselves to be British and worthy of such an inheritance. And all this formed a political culture that emphasised 'the quality of the men elected into Parliament and political office rather than the way the political structure operated' (Melleuish 2013: 1, 6).

In addition to Britain, though, Australians looked throughout the century to America for measures of quality. In 1827 the editor of the 'conservative' Sydney Gazette praised the appointment of George Druitt - major, settler and landowner and a man with political enemies - as a 'modern Cincinnatus [who] has proved an ornament and beneficial appendage to his fellow-Colonists'. He has 'manifested the uprightness, correctness, and honour of a Gentleman, and his estate displays the state of a true English farmer' (Anonymous 1827: 2). Such common references to Cincinnatus easily and often extended to favourable mention of Washington. The Sydney Monitor, started in 1826 and considered more in the 'liberal' camp, reproduced in 1832 from Tait Magazine of Edinburgh an article with the caption that it was 'a great deal too true'. It examined the virtues of chancellor Lord Brougham and decided 'we are looking for the patriotism of a Regulus, the self-denial of a Scipio Africanus, and the magnanimity of a Cincinnatus, or a Washington'. We see an early demonstration of the gap drawn between ancient examples of leadership and contemporary leaders: 'It only leads us to regret, that in the present day, your Broughams, Greys, and Radnors, seldom equal the expectations of mankind, and fall short of the ancient heathen Patriots (Anonymous 1832: 2). In 1860, one letter wrote, 'without supposing that we have among us a Cincinnatus or a Washington', on the vexed issue of finding the fit parliamentarians who were not "'restless demagogues" and "unfit men"' (Citizen 1860: 5). In 1887 Wybert Reeve, an actor and author famous in his time, gave a public lecture on heroes of 'incorruptible truth and devotion to a great cause'. Amongst their number he included Cincinnatus as well as Washington 'with his integrity of character, and a sense of justice so great that no influence could swerve it from the proper course' (Anonymous 1887: 6).

As we saw earlier, qualities of American leaders were a part of American populism, a rhetoric and decorum that found ready recipients in early Australia. It was always possible for the emancipists to refract local struggles through the populist lens and to see the exclusives working in similar cabals and conspiracies to those operated by American aristocrats. In particular, Jackson's vitriolic attacks on the Bank of the United States in 1832 made him a popular hero fighting a body that made 'the rich richer and the potent more powerful' (Greenstein 
2009: Chpt 8, location 18). Hence the liberal Morning Chronicle derided the Sydney Morning Herald and its advocacy of the 'Pure Merino gentlemen' and their 'Pure Merino Bank' or Bank of Australia (Anonymous 1845a: 2). As it had on many occasions, the Chronicle invoked Old Hickory, as Jackson was known, against money interests and so did Reverend Dr John Lang with his audiences. Adelaide readers received extracts from 'the democratic paper', the Daily Boston Times, celebrating the victory of James K. Polk, who was christened 'the Young Hickory' for carrying the legacy of his predecessor over Henry Clay (Anonymous 1845b: 3). The same raging rhetoric against financial conspiracies arose with the Labour Party in the 1890s (Love 1984), at the same time that the Populist Party made famous inroads on American politics. The rhetoric lived on for decades.

A democratic rhetorical style and ethos accompanied this populist politics as it did in America. Again, Wentworth was an exponent since he was the point man 'for an assortment of bond and free, indigent and wealthy, needy men and hangers-on, knock-abouts and ne'er-do-wells'. The Australian was their 'scandalous, vitriolic rag that exhibited no respect for legitimate authority, according to the exclusives' (Cochrane 2006: 17). Their man was notorious for 'virulent abuse', 'scandalous and vituperative imputations' and 'the filth of the missiles hurled from his mud-cart' (Cochrane 2006: 3).

From its earliest days politics in Australia was rowdy, raucous and replete with hortatory admonitory rhetoric that divided people according to the politics of the time. In other words, it was similar to America and we see similar assessments about ethos made with judgements of rhetorical decorum. In 1829 Governor Ralph Darling found an implacable opponent in the irascible Wentworth who sought his recall and impeachment and who had support in his quest from many newspapers. Darling thought the 'style and matter' of Wentworth's language was 'the best criterion of his character and motives'. In other words, he was 'a vulgar, ill-bred fellow, utterly unconscious of the Common Civilities due from one gentleman to another' (Cochrane 2006: 514). Darling had support from the Sydney Gazette, which was on the side of the established order, and damned Wentworth as a 'factious partisan' and pompously advised him to 'cultivate the arts of fair, upright, gentlemanly controversy, treating with candour, if not with civility, those whose opinions may happen to clash with his own, and shunning, as he would shun a grey snake, the vulgar epithets and phraseology of the pothouse, and the abusive slang of the milling-ring' (Anonymous 1829b: 2).

Clearly, in a similar fashion to America, views of rhetorical style aligned with political stance on populist causes. The Sydney Morning Herald of that time has been labelled conservative and in that vein it reproduced from the English Fisher's Colonial Magazine a review of a book of Clay's life and speeches. Clay was an appropriate choice for those who preferred the literary and gentlemanly style of rhetoric over the boisterous democratic style of Jackson, since the Herald 
feared democracy and the working class. Consequently, the reviewer favourably compared the Tory Edmund Burke, 'the unequalled Hibernian Cicero' to 'the classical and ornate' style of Clay (Anonymous 1845c: 4). For the editor of the Hobart Courier in 1852 the quality of rhetoric was connected to the quality of leadership of the 'great future for these our southern confederate republics'. He was mourning the death of Clay, a man 'gifted with great power of persuasion', with an antipodean sentiment:

To us, in these Australasian colonies, the younger children of the AngloNorman family, not without note or instructiveness do such men as Henry Clay pass from the theatre of action ... In that fast-coming time none could utter a more benevolent wish for the welfare of Australasia than that a man or men like Henry Clay should be raised up to lead and to counsel these youthful communities (Anonymous 1852: 2).

Sixty years after the death of Clay, a Melbourne newspaper could still refer to him as 'a genius' of oratory who acquired fame through hard work (Anonymous 1912: 3). Given that to date Australia followed the American battles over democracy and rhetoric, we were bound to also follow the next phase in the construction of rhetorical and presidential traditions, which included someone so often admired these days for oratorical greatness.

\section{Lincoln and the middling style}

Lincoln was subject during his presidency to the sort of abuse that is regularly dished out these days at politicians and it was directed as much at his middlingstyle rhetoric as at his character. The two were linked in many minds. Democratic and Republican politicians alike called him the 'original gorilla', which was an attack on his ethos in connection to the lack of refinement displayed by his language. After a meeting at the White House, even a sympathetic Republican was confused by his style and called him 'a barbarian, Scythian, yahoo or gorilla' because of his linguistic lapses (Cmiel 1990: 119).

Lincoln was in the middle of the battles over rhetorical style connected to character. He was a 'slang-wanging, stump speaker' (Williams 2001: 140) to one critic. One reporter heard the Gettysburg Address and reported: 'The cheek of every American must tingle with shame as he reads the silly, flat dish-watery utterances of the man who must be pointed out to foreigners as the President of the United States' (Spiegel 2002: 246). A February 1864 editorial in the influential New York Herald exclaimed: 'The idea that such a man as he should be President of such a country as this is a very ridiculous joke ... His inaugural address was a joke' (Dallek 2001: xiii). A paper in his home state called him 'The craftiest and most dishonest politician that ever disgraced an office in America' 
(Boller 1996: 127). Not only was Lincoln criticised for his style, but also subject to the stereotype of politicians that has been common to Australia since the beginning and to Britain since the Robinocracy.

The accompanying point to be made here is that it has always been an advantage for politicians to trade on the disrepute of politicians because the public has readily believed the worst of them. Tony Abbott has found eager audiences for such attacks when he railed successfully against a politicians' republic in 1998 and, more recently, accused Julia Gillard of being a liar. Abbott is only the latest in generations of politicians that have successfully accused opponents of lies. In particular, political neophytes across Anglosphere countries have had striking success with this ad hominem through parading their own lack of experience in the political game against the disrepute of the political establishment. So one finds this connection in rhetorical topos between such disparate political forces as the first Labor members of the NSW parliament in 1891, Pauline Hanson in 1996, the Australian Democrats in the 1970s and Jefferson Smith, the main character in the famous 1938 Hollywood movie Mr Smith Goes to Washington (Rolfe 2008). Perhaps the most successful and famous recent example, however, was Barack Obama's 2008 advancement of his political innocence against the dirty politics of Washington in combination with appeals to the great Lincoln and the jeremiad.

It was ever thus with American populism, which has always encouraged the ideal and the anti-political at the same time. Even though Lincoln was accused of dishonesty, he was not above exploiting the stereotype of politician to bolster his own ethos. In 1837 he told the Illinois legislature 'Mr Chairman, this movement is exclusively the work of politicians, a set of men who have interests aside from the people and who, to say most of them, are, taken as a mass, at least one long step removed from honest men. I say this with greater freedom because being a politician myself, none can regard it as personal' (Spiegel 2002: 2).

Death did not immediately vault Lincoln into the pantheon of democratic heroes whose rhetoric is treasured. It took decades. His gradual metamorphosis, however, demonstrates the larger point about the evolving tradition of standards of leadership and rhetoric, in America and elsewhere. Until the turn of the century Lincoln was the partisan preserve of the Republicans to be wielded against Democrats. The battle extended to his rhetoric as well. Edward McPherson was a Republican congressman and, later, a keeper of the Lincoln flame, so to speak, as an officer of the Gettysburg Battlefield Memorial Association. As American and Australian readers found (Anonymous 1887), McPherson claimed 'it is strange that the genuine literary abilities of the man were so long and persistently ignored by literary people'. This was not so strange given the partisan divide over the middling style. Lincoln, he said: 
knew that cultivated men, even after his debates with Douglas, and after his first inaugural, were of opinion that he was utterly without other literary powers than those of a good stump speaker. He was believed to be a man of strong character, but wholly without literary polish, and it was generally believed that such a polish as his greatest speeches, such as that delivered in Cooper Institute in the winter revealed, was the work of some cultivated friends or some skilful secretaries. (Anonymous 1888: 7)

In nineteenth century England, Lincoln was abhorred by the Tories and aristocrats who associated him with the 'mob rule' of democracy. Alternately, Lincoln was a hero to liberals and labourites until World War II because they considered him a champion of the ordinary people (Smith 2011: 125-27). In this category of political celebration he was joined by such admired Liberal heroes as John Bright, Giuseppe Garibaldi and, of course, William Gladstone. This was, says Smith, 'radical political celebrity culture' that helped to perpetuate Liberalism as a radical tradition well into the next century. Winston Churchill was engulfed by it. Importantly, it was a British Liberalism that had learnt much from America as a test of the 'democratic principles of progress and liberty', which they fervently supported (Gerlach 2001: 5). Most of all there was Gladstone, nicknamed 'The People's William' for his recognition of public opinion and admired for his oratory.

\section{Deification of Lincoln}

It was only in the early twentieth century that Lincoln was transmuted 'from flawed politician [into] secular deity' (Zarefsky 1986: 363) to be fought over by all sides of American politics. By then he had joined the 'invented tradition' of mythologised presidents along with Washington, Jefferson and Jackson to be used and abused for partisan purposes. A further result of secular deification was that his rhetoric became a model to follow not an idiosyncrasy to scorn. He was no longer the crafty dissembler nor the awful purveyor of the middling style. Instead his rhetoric was elevated from its context. Politicians from Walter Mondale in 1984 to Newt Gingrich and the Texas Tea Party in 2011 (Camia 2011) have called for the emulation of the Lincoln-Douglas debates of 1858, with the intent of boosting their own ethos with a public that is widely suspicious of politicians and political rhetoric. The debates are, however, 'vastly more admired than read' (Zarefsky 1986: 162) and their reputation 'far outweighs their value' (Holzer 2012).

Lincoln's political metamorphosis in the early twentieth century was not only an American phenomenon but also British and Australian. The cult of Lincoln rose aloft a sentiment of Anglo-Saxon community that redescribed the man as 
the embodiment of English values. The mission of American exceptionalism and the role of British imperial defender of liberty merged in the racial ideology of Anglo-Saxonism. This was most needed during World War I when the struggle was seen as a fight against a Prussian militarism, just as the Civil War was a fight against slavery. In Edwards' words 'Lincoln's image was "internationalized" during the war' (2013: 30) under the auspices of Anglo-Saxon racialism.

Naturally, in Britain the Welsh Prime Minister David Lloyd George invoked Lincoln just as easily as did his Welsh counterpart Prime Minister William Hughes in Australia, who was often hailed from 1916 onwards as another Lincoln. This approbation was given by the New York Herald (Anonymous 1916a: 5), but closer to home even the premier of South Australia was willing to say:

At present Mr. Hughes was in a similar position to that which faced Abraham Lincoln, when the great American President had to resort to compulsion against his wishes and sentiments. Lincoln was assailed, and Mr. Hughes was being assailed ... He took his stand beside Mr. Hughes. If any penalty was to be meted out to the Prime Minister, all honour to him for daring to do what was right in the face of opposition which he did not think was fair. (Anonymous 1916b: 5)

With this wartime context in mind, a biographer insisted on ranking Hughes with the great Lincoln (Anonymous 1916c: 4). Such repeated associations had obvious ethical purpose against opponents during the conscription debates, presenting them as on the wrong side of the fight for democracy. This was the case of Liberal leader Joseph Cook in building the case for a referendum by pointing to Lincoln's conscription during the civil war (Anonymous 1916d: 5). Lincoln was also a continuation of Hughes's fascination with symbols of radical Liberal sympathies for the working class. On train trips to Melbourne for parliament he often practised oratory by listening to recordings of Gladstone's speeches. Obviously he was a model of oratory for the young Hughes.

The cult of Lincoln continued after the war. British and Australian newspapers called Prime Minister Stanley Baldwin a second Lincoln or a miniature Lincoln. In 1929, new prime minister James Scullin was 'Another log cabin to White House story', according to one journalist, in the tradition of Lincoln, as were his predecessors John Christian Watson, Andrew Fisher and Billy Hughes. Scullin did not stack up against Alfred Deakin, who had of course the reputation as 'Australia's greatest orator'. This journalist seems put off by Scullin's more hortatory style.

At times he emphasises the 'soap box'-type of oratory, which, while aggressive, is not always appreciated by those unaccustomed to the stresses of inflammatory speech. (Anonymous 1927: 22) 
By then, the dead Deakin's style was being favourably compared to that of the even longer dead Gladstone (Jose 1933: 19). Yet we can still see how the middling style had become commonplace in the twentieth century. On the one hand Prime Minister Robert Menzies displayed the erudite side with his insertion of poetry into his speeches, most infamously his 1963 speech to the Queen, although by then the change in endoxa had rendered this aspect of the decorum obsolete. On the other hand, during his state election campaign in 1929, Menzies told an audience in Malvern: 'What we want in politics today is plain speech about plain subjects for plain people' (Anonymous 1929: 7-8). As we know, Menzies was an admirer of Baldwin, the second Lincoln, who cultivated the plain folksy style and ethos disclaiming any oratorical pretensions. So it was only a short rhetorical leap to Howard in 1988, who projected the ethos of the plain thinking man with Future Directions, but without any of the literary aspects expected of middling style. In 1929 Menzies also highlighted his reformist and Young Turk ethos and, in the process, protested against the dissembling often associated with politics. Thus, to another audience, he deployed the stereotype of politicians to state 'the political occupation is regarded as one which a really intelligent and decent person does not bother about' (Martin 1993: 66, 72-73).

Come World War II, Lincoln was again enlisted to the Allied and Anglo-Saxon cause on behalf of democracy and against militarism. Lincoln's words and visage appeared in speeches, statues, radio plays and especially in films such as Young Mr Lincoln and Words for Battle, both of which were widely distributed in Australia. The latter was a documentary offering a 'potted history of the idea of liberty in English history' (Smith 2010: 503). Again the cause of Anglo-Saxonism connected England, America and Australia in war, but with a difference. Now Churchill's words had joined those of Abe, Milton, Browning, Blake and Kipling. He had joined the rhetorical tradition with the man he greatly admired in his own History of the English-speaking peoples.

This chapter has discussed rhetorical standards in terms of history, tradition and myths that have been part and parcel of continuing debates in three political societies going back to the early 1700s. The ultimate point to be made about these standards is that they cannot be considered as impeccably distinct from the rhetoric they judge. They are part of the continuing political contests and discussions that are the essence of representative democracy. In other words, they have arisen endogenously from social practices, rather than being imposed on people from above. This is the stance of John Dryzek (2002: 1), Iris Marion Young (2003: 7, 47, 65, 154) and Chantal Mouffe (2000: 5-6) who are critical of Jurgen Habermas's projection of ideal political discourse. Against charges of not existing in the world, the ideal has been defended as something to aim for and as a regulative 'fiction', a 'presupposition', such that 'we act counterfactually as though the ideal speech situation ... were not merely fictitious but real' (2001: 
102). But this chapter has demonstrated that Habermas is following many others who have projected similar regulative fictions and used them persuasively in political combat. Such abstractions have always been appealing but cannot be considered as floating somewhere beyond the political realm. They are part and parcel of political conflict.

\section{References}

Anonymous 1825. New South Wales - Extract of a letter inserted in Morning Chronicle. Australian 3 March.

Anonymous 1827. Shipping intelligence. Sydney Gazette and New South Wales Advertiser 25 June.

Anonymous 1829a. Franklins prophecy: To the editor of the Sydney Gazette. Sydney Gazette and New South Wales Advertiser 9 July.

Anonymous 1829b. Advance Australia. Sydney Gazette and New South Wales Advertiser 24 December.

Anonymous 1831. The value of a representative government. Australian 29 July.

Anonymous 1832. Beer or Wine?: To the editor of the Sydney Herald. The Sydney Monitor 15 September.

Anonymous 1845a. The Bank of Australia, or 'Pure Merino' Bank. Morning Chronicle (Sydney) 8 February.

Anonymous 1845b. American news. South Australian 15 April.

Anonymous 1845c. Review. Sydney Morning Herald 27 May.

Anonymous 1852. Henry Clay. Courier (Hobart) 10 November.

Anonymous. 1887. Abraham Lincoln and his Gettysburg Oration. Maitland Mercury \& Hunter River General Advertiser 25 June.

Anonymous 1887. Heroes: A Lecture By Mr. Wybert Reeve. South Australian Register 25 October.

Anonymous. 1888. Written On His knee: How Lincoln Composed His Celebrated Gettysburg Oration. Logansport Journal 27 June. p 2.

Anonymous 1912. Genius and hard work. North Melbourne Courier and West Melbourne Advertiser 22 November. 
6. Looking backwards to the future: The evolving tradition of ideal political rhetoric in Australia

Anonymous 1916a. Appreciation of Mr. Hughes: 'Australia's Abraham Lincoln', Morning Bulletin (Rockhampton) 20 July.

Anonymous 1916b. Campaign in progress. Register (Adelaide) 18 September.

Anonymous 1916c. Reviews. Register (Adelaide) 29 July.

Anonymous 1916d. The question of the hour. Register (Adelaide) 14 September.

Anonymous 1927. Recent publications: A great Australian statesman. Advertiser (Adelaide) 3 December.

Anonymous 1929. Public questions. 'Plain speech' advocated. Argus (Melbourne) 14 November.

Bailyn, B. 1968. The origins of American politics. New York: Vintage Books.

Bercovitch, S. 1978. The American jeremiad. Madison, W.I.: University of Wisconsin Press.

Boller, P. 1996. Presidential anecdotes. New York: Oxford University Press.

Brown, W.B. 1960. The people's choice: The presidential image in the campaign biography. Baton Rouge: Louisiana State University Press.

Camia, C. 2011. Cain, Gingrich set for Lincoln-Douglas debate. USA Today 26 October. URL: http://content.usatoday.com/communities/onpolitics/post/2011/10/lincolndouglas-debate-newt-gingrich-herman-cain-/1. Consulted 13 May 2012.

Citizen, 1860. Payment of members of parliament. South Australian Weekly Chronicle February.

Cmiel, K. 1990. Democratic eloquence: The fight over popular speech in nineteenthcentury America. New York: William Morrow \& Co.

Cochrane, P. 2006. Colonial ambition: Foundations of Australian democracy. Melbourne: Melbourne University Press.

Connolly, W. 1983. The terms of political discourse. Oxford: Martin Robertson.

Condren, C. 1997. Political theory and the problem of anachronism. Political theory: Tradition and diversity. Cambridge: Cambridge University Press.

Crabb, A. 2013. Has the news cycle killed soaring political oratory? The Drum 27 May. URL: http://www.abc.net.au/news/2013-05-27/crabb-politicalspeech/4714004. Consulted 1 August 2013.

Dallek, R. 2001. Hail to the chief: The making and unmaking of American presidents. Hyperion Books. 
Studies in Australian Political Rhetoric

Dunn, J. 2006. Setting the people free: The story of democracy. London: Atlantic Books.

Dryzek, J. 2000. Deliberative democracy and beyond: Liberals, critics, contestations. Oxford: Oxford University Press.

Eastman, C. 2009. A nation of speechifiers: Making an American public after the revolution. Chicago: University of Chicago Press.

Edwards, S. 2013. 'From here Lincoln came': Anglo-Saxonism, the special relationship, and the anglicisation of Abraham Lincoln, c. 1860-1970. Journal of Transatlantic Studies 11(1): 22-46.

Flood, C. 2002. Political Myth. New York: Routledge.

Gerlach, M. 2001. British liberalism and the United States: Political and social thought in the late Victorian age. Basingstoke: Palgrave MacMillan.

Greenstein, F. 2009. Inventing the job of President: Leadership style from George Washington to Andrew Jackson. Princeton: Princeton University Press.

Habermas, J. 2001. On the pragmatics of social interaction: Preliminary studies in the theory of communicative action. Trans. B. Fultner. Cambridge, Mass.: The MIT Press.

Hanson, R. 1985. The democratic imagination in America: Conversations with our past. Princeton: Princeton University Press.

Holzer, H. 2012. The Lincoln-Douglas debates weren't as great as Gingrich thinks. Washington Post 28 January 2012. URL: http://www.washingtonpost. com/opinions/the-lincoln-douglas-debates-werent-as-great-as-gingrichthinks/2012/01/25/gIQABwX1VQ_story.html. Consulted 10 August 2013.

Jose, A. 1933. Some famous men: What Alfred Deakin did for Australia. Brisbane Courier 4 February.

Kazin, M. 1998. The populist persuasion: An American history. Ithaca, N.Y.: Cornell University Press.

Love, P. 1984. Labour and the money power: Australian labour populism 18901950. Carlton: Melbourne University Press.

Manne, R. 2007. The nation reviewed. The Monthly April.

Martin, A. 1993. Robert Menzies: A life. Vol. 1. Carlton: Melbourne University Press. 
6. Looking backwards to the future: The evolving tradition of ideal political rhetoric in Australia

McLachlan, N. 1977. The future America: Some Bicentennial reflections. Historical Studies 17 (April): 361-83.

Melleuish, G. 2013. Personal politics and being British: Political rhetoric, democracy and their consequences in colonial New South Wales. Australian Journal of Politics \& History 59(1): 1-14.

Mouffe, C. 2000. Deliberative democracy or agonistic pluralism. Vienna: Institute for Advanced Studies. URL: http://www.ihs.ac.at/publications/pol/pw_72. pdf. Consulted 22 August 2013.

Parry-Giles, T. 2010. Resisting a 'treacherous piety': Issues, images, and public policy deliberation in presidential campaigns. Rhetoric \& Public Affairs 13(1): 37-63.

Patapan, H. 2003. Melancholy and amnesia: Tocqueville's influence on Australian democratic theory. Australian Journal of Politics \& History 49(1): 1-16.

Robertson, A. 2005. The language of democracy: Political rhetoric in the United States and Britain, 1790-1900. Charlottesville, V.A.: University of Virginia Press.

Rolfe, M. 1997. The promise and threat of America in Australian politics. Australian Journal of Political Science 32(2): 187-204.

- 2008. New wine into old bottles: Ethical appeals and democratic discourse. Australian Journal of Political Science 43(3): 513-29.

Sartori, G. 1987. The theory of democracy revisited. Chatham: Chatham House Publishers.

Saward, M. 2003. Democracy. Cambridge: Polity.

Schudson, M. 1978. Discovering the news: A social history of American newspapers. Basic Books.

Smith, A. 2010. The 'cult' of Abraham Lincoln and the strange survival of liberal England in the era of the World Wars. Twentieth Century British History 21(4): 486-509.

- 2011. Lincoln in the English imagination. In R. Cawardine and J. Sexton eds. The Global Lincoln. New York: Oxford University Press.

Smith, J. 2009. Presidents we imagine. Madison, W.I.: University of Wisconsin Press.

Spiegel, A. 2002. A. Lincoln Esquire: A shrewd, sophisticated lawyer in his time. Macon: Mercer University Press. 
Tanner, L. 2012. Sideshow: Dumbing down democracy. Carlton: Scribe Publications.

Tardini S. 2005. Endoxa and communities: Grounding enthymematic arguments. Studies in Communication Sciences. Argumentation in dialogic interaction. Special issue: June.

Tudor, H. 1972. Political Myth. London: MacMillan.

Walton, D. 2007. Media argumentation: Dialectic, persuasion and rhetoric. New York: Cambridge University Press.

Williams, F. 2001. Abraham Lincoln - Our ever present contemporary. In J. McPherson ed. We cannot escape history: Lincoln and the last best hope of Earth. Urbana: University of Illinois Press.

Young, I.M. 2003. Inclusion and Democracy. Oxford Scholarship Online.

Zarefsky, D. 1986. The Lincoln-Douglas debates revisited: The evolution of public argument. Quarterly Journal of Speech 72: 162-84. 
This text taken from Studies in Australian Political Rhetoric, Edited by John Uhr and Ryan Walter, published 2014 by ANU Press, The Australian National University, Canberra, Australia. 